The project is to examine the possible pharmaceutical uses of the lymphocyte chalone, which has an inhibiting effect on cell division. The grant is from the Australian section of Aspro-Nicholas Ltd., who intend that an Australian university department will also be associated with the work.

\section{Alcohol and Flying}

The Civil Aviation Authority has issued an information circular $(112 / 1973)$ reminding pilots of the loss of performance from even a modest intake of alcohol. Alcohol taken by the pilot was a contributory factor in three fatal accidents involving light aircraft in 1973. Research has confirmed that blood alcohol concentrations of $40 \mathrm{mg} / 100 \mathrm{ml}-$ that is, half the legal driving limit-are associated with important increases in pilot error, in both experienced and inexperienced flyers. Aeronautical Information Circular United Kingdom 112/1973 26 November, may be obtained from Aeronautical Information Service (AIS 1), Tolcarne Drive, Pinner, Middlesex, HA5 2DU. Tel: 01-866 8781 ext. 259.

\section{Medical Biophysics Research}

The Scottish Home and Health Department has allotted $£ 15,800$ to Professor John Martin in the department of medical biophysics, University of Dundee. The grant is to provide an ultra-fine focus $x$-ray plant and xeroradiography unit for evaluation in research and clinical use. Evaluation studies using the xeroradiographic equipment will be carried out by Dr. C. Pickard at Dundee Royal Infirmary, and laboratory and clinical trials of both systems are to be carried out in Dundee Dental Hospital and in Ninewells and associated hospitals.

\section{COMING EVENTS}

Royal College of Physicians of London.Growing points in medicine session, "Abdominal Pain and Diarrhoea," 12 December. For details see advertisement on page xiv.

King Edward's Hospital Fund for London.Day conference, "Admission of Patients to Hospital," 18 December, Sir Francis Avery Jones will preside. Fee $£ 2$ (including lunch). Application forms and details from Miss R. Barnett, King's Fund Centre, 24 Nutford Place, London W1H 6AN. (Tel. 01-262 2641.)

Nufiield Department of Orthopaedic Surgery, Oxford University.-Series of lectures, the second half of a postgraduate course, "Basic Sciences of the Musculoskeletal System," Friday evenings, 6.30 p.m., and Saturday mornings, 8.30 a.m., 4 January-16 March inclusive, at Nuffield Orthopaedic Centre, Oxford. Members of medical and allied professions are invited. Details from the centre. (Tel. Oxford 64811.)

Institute of Urology.-Day symposium, "Renal Stone," 19 January. For details see advertisement on page xiii.

7th International Hospital Symposium.-31 January-1 February, Düsseldorf. Details from the secretariat of the symposium, Deutsches Krankenhausinstitut E.V., Düsseldorf University, 4000 Düsseldorf 30, Tersteegenstrasse 9, Germany.

London Medical Group.-Annual conference, in conjunction with Society for the Study of
Medical Ethics, "To Treat or Not to Treat," 8-9 February, Royal College of Surgeons of England. Details and application forms from the conference secretary, L.M.G., Tavistock House East, Tavistock Square, London WC1H 9LG. (Tel. 01-387 2129.)

Manchester Medical Society.-Copies and details of the programme, December-February, are obtainable from the secretary of the society, Manchester University, Manchester, M13 9PL. (Tel. 061-273 6048/3074.)

\section{SOCIETIES AND LECTURES}

For attending lectures marked a fee is charged or a ticket is required. Applications should be made first to the institution concerned.

\section{Monday, 10 December}

INSTITUTE OF LARYNGOLOGY AND OTOLOGY.-5.30 p.m., Dr. A. D. Dayan: Virus Diseases of the

ROYAL CoLLEG OF SuRgeons OF ENGLAND.-4.30 p.m., Erasmus Wilson demonstration by Professor D. E. Poswillo: Causal Mechanism of
Anomalies invoked by Thalidomide.

\section{Tuesday, 11 December}

Quekn Charlotte's Maternity Hospital, LonDON.-5 p.m., Beecham lecture by Professor S. G. Clayton: Are We Doing Any Good?

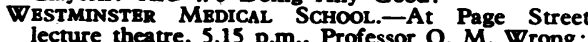
Clinicopathological conference.

Wednesday, 12 December

Royal. Colleg of Obstetricians and Grnaecologists. -4.30 p.m.' Postgraduate museum
demonstration by Dr. J. O. W. Beilby: The Blood demonstration by Dr. J. O. W. Beilby: The Blood the Possible Mechanisms of Abnormal Uterine Bleeding.

ROYAL COLLEG OF SURGgons OF ENGLAND. -5 p.m., Bradshaw lecture by Mr. R. H. Franklin:
Oesophageal Surgery.

Thursday, 13 December

HONYMAN GHLespis Lecture.-At Royal Infirmary, Edinburgh, 5 p.m., Mr. C. V. Ruckley: Diagnosis and Prevention of Venous Thromboembolic RoYal Colleg of Surgrons of ENGLAND.-A Institute of Ophthalmology, 3 p.m., EderidgeGreen lecture by Dr. K. Kirschfeld: The Com-
pound Eye of the Fly-Differences and Analogies pound Eye of the Fly-Differences and Analogies HYGIBNB. 7.30 p.m., Symposium: The Haemo-
globinopathies.

Friday, 14 December

Nationai Hrart Hospital.-At Royal College of Physicians of London, 5.45 p.m., St. Cyres lecture Myocardial Infarction

Royal Collagg of Physicians of Edingurgh.7 p.m., McGibbon memorial lecture by Professor the Bowrel.

Royal Postgraduate Mepical School.-11 a.m. Professor H. H. Wandall (Copen

\section{UNIVERSTTIES AND COLLEGES}

\section{CAMBRIDGE}

M.D.-M. E. French, D. G. Leaver, G. H. Elder

\section{ABERDEEN}

Appointments.-Dr. J. Elizabeh Macgregor (senior (lecturer, mental health)

\section{LONDON}

M.D.-B. Fox, T. N. Stanbridge.

Pr.D.-In the Faculty of Medicine: Patricia $M$ Foreman, J. Silver, S. Sinnatamby, Jennifer S Wakelin, H. H. Chissick, H. Desai, P. L. Lantos, Macanovic, F. A. Og,unbona

Macanovic, F. A. On the Faculty of Medicine: R. Beaglehole, A. R. Griew, G. Heiss, H. McDonnell, D. M. J. R. Wilkie, K. R. Woodcock.

SHEFFIELD

The title of emeritus professor has been conferred physiology, 1946-73.

\section{APPOINTMENTS}

Birmingham Rggional Hospital BOARD--Dr. W. J. Norman (consultant radiologist, Shrewsbury group); ency services, East Birmingham group); Mr. R. H. Grace (consultant surgeon, Wolverhampton group); Dr. P. Naish (consultant physician, including nephrology and renal immunology, North Staffs group); Dr. G. E. Strang (consultant psychiatrist, (consultant orthopaedic and traumatic surgeon. Walsal group); Dr. A. B. Clymo (consultant paediatrician, Wolverhampton group); Dr. K. K. Dutt (consultant Richer (consultant ophthalmologist, Wolverhampton in adult psychiatry, Coventry and South Warwickshire group); Mr. M. T. Reynolds (consultant
orthopadeic surgeon, South Warwickshire group);
Dr. G. Dickens (consultant psychiatrist, West Birmingham group); Dr. B. D. Mukerii (consultant anaesthetist, Mid-Worcestershire group); Dr. J. A. anaesthetist, Mid-Worcestershire group); Sr. J A. group); Dr. M. J. O'Shea (consultant haematologist, Shrewsbury group); Dr. M. A. Sandhu (consultan anaesthetist, North Staffordshire group); Dr. M. S Khan (consultant microbiologist, South Warwickshire group); Dr. M. Pabari (consultant anaesthetist, West Bromwich group); Dr. J. R. Riordan (consultant physician, with special interest in chest diseases,

\section{Corrections}

\section{Amphotericin Pharmacophobia}

In the article "Amphotericin Pharmacophobia" (24 November, p. 460 ) by $W$. St C. Symmers, the 7th line in the paragraph headed Case 4 should read (Symmers, 1973) not (Symmers, in press). Also the reference Symmers, W. St C. (In press) Curiosa-A Miscellany of Clinical and Pathological Experiences, chap. 21. London, Balliere Tindall, should be omitted.

Changes in Skeletal Mineral in Patients on Prolonged Maintenance Dialysis

We regret that in the paper on Changes in Skeletal Mineral in Patients on Prolonged Maintenance Dialysis (1 December, p. 519) "dihydroxycholecalciferol" was spelt incorrectly in the tenth line of the Summary and the sixth line of the last paragraph under Discussion.

\section{Medicine in the Common Market}

In Professor Franco Perraro's paper on "Young Hospital Doctors" in the R.S.M. symposium on "Medicine in the Common Market" (24 November, p. 480) the penultimate sentence of the third paragraph under the heading Hospital Doctors' Collective Agreement should have read: "A young doctor with 1,000 I.N.A.M. patients is paid six million lire a year by the Institute."

\section{Notice to Authors}

When original articles and letters for publication are not submitted exclusively to the British Medical fournal this must be stated. Accepted articles may subsequently be selected for publication in the North American monthly edition.

Correspondence on editorial business should be addressed to the Editor, British Medical fournal, B.M.A. House, Tavistock Square, London WC1H 9JR. Telephone: 01-387 4499. Telegrams: Aitiology, London, W.C.1.

Authors wanting reprints of their articles should notify the Publishing Manager, B.M.A. House, Tavistock Square, WC1H 9JR, on receipt of proofs.

\section{(C) British Medical Journal 1973}

All Rights Reserved. No part of this publication may be reproduced, stored in a retrieval system, or transmitted, in any form or by any means, electronic, mechanical, photocopying, recording or otherwise, without the prior permissson of the British Medical Yournal. 